Horn Head; the fronds were fertile at the time notwithstanding that the plant has been usually quoted as flowering in January. Mr. Hart further points out that the claims of this fern to a place in the British flora have hitherto rested upon its known habitat in Guernsey.

Is the June number of The California Horticulturist, amongst other articles of horticultural and local interest, is one on the Sierra Forests, pointing out the great risk there is of these magnificent forests becoming denuded as"they "are now and for many years have been, at the mercy of private greed and public theft." The writer says it is true no changes are yet manifest, there are miles of forest left, and ravines wherein no chopper's axe has yet resounded. It is not the axe that is feared but the sheep and cattle owned by private individuals that have for years been pastured on the Government lands of the Sierras. The common practice, it is said, has been for a man having perhaps five or ten thousand head of sheep to purchase one single quarter section from the Government to build his house on, and perhaps to hold the best springs of water. From that central point his flocks and herds roam for miles, under the spicy pines and cedars, trampling the soft rich ground until it is like iron, destroying every seed, killing all the young trees, and causing the State a.yearly loss in the value of her forests, which is far more than the worth of the whole band of sheep. The article concludes with a reference to the matter having occupied the attention of some of "our best thinkers." "Prof. Sargent, of Harvard," we are told, "points out in the Nation the disastrous effects of such a policy; Prof. Hooker, of Kew Gardens, follows in the same line of thought; and John Muir mourns over the desiccated forest-shrinez, and the rarer flowers and ferns, now rapidly passing out of existence."

Messes. Longmans and Co. have just issued a little book on "Town and Window Gardening," being the substance of a course of lectures "given out of school hours to pupil teachers and children attending the Leeds Board Schools." These lec. tures were given by Mrs. C. M. Buckton, a member of the Leeds School Board, and author of two recently published books called respectively "Health in the House," and "Food and Home Cookery." These endeavours of Mrs. Buckton to raise the moral and intellectual welfare of the working classes are highly praiseworthy, and though the book before us may not claim a position amongst standard scientific works, yet there is much that is good scattered. through it which cannot fail to raise the tastes of many a child fortunate enough to come under the influence of teachers like the authoress who have a real admiration for nature in all its branches and a heartfelt desire to impart as much knowledge as possible to the children of our crowded alleys.

THE Tasmanian gold-fields are reported to be very successful, and some rich finds have occurred on the Pieman River. The locality is about seventy miles across country from the tin deposits at Mount Bischoff. Numbers of people are flocking to the diggings from all quarters.

THE additions to the Zoological Society's Gardens during the past week include a Weeper Capuchin (Cebus capucinus) from Guiana, presented by Capt. Bond; a Brown Bear (Ursus arctos) from Russia, presented by Mr. J. R. Boyce; a Tawny Eagle (Aquila navioïdes) from Southern Spain, presented by the Marquis de la Granja; a Bateleur Eagle (Helotarsus ccaudatus) from the Isle de Bas, Sierra Leone, presented by Mr. Alex. Sinclair; two common Crossbills (Loxia curvirostris) European, presented by Mr. H. A. Macpherson ; a Common Cuckoo (Cucuhus canorus), British, presented by Miss C. Bealey; a Central American Agouti (Dasyprocia isthmica) from Central America; two White-faced Tree Ducks (Dendrocygna viduata), a Redbilled Tree Duck (Dendrocygna autumnalis) from Rio Magdalena, purchased.

\section{SOUTH CAROLINA FOSSILS}

IN a paper on "Vertebrate Remains, chiefly from the Phosphate Beds of South Carolina," published in the Fournal of the Academy of Natural Sciences of Philadelphia (vol, viii. part iii.), Prof. Joseph Leidy prefaces his careful description of the many separate remains by a few general remarks on the subject, some extracts from which may interest our readers. The fossils are mainly from the so-called Ashley phosphate beds of South Carolina, which "are composed of sands anc clays, intermingled with irregular porous masses of more coherent rock rich in calcium phosphate, together with many organic remains. These beds, the economical importance of which was fully made known in 1868 by Prof. Francis S. Holmes and Dr. N. A. Pratt, of Charleston, occupy a large extent of country in the southern part of South Carolina, on the Wando, Cooper, Ashley, Stono, Edisto, Coosaw, Asheepo, and other rivers. According to Prof. Holmes, from 'fifteen to eighteen inches may be considered the average thickness of the stratum of the phosphate rocks.'1

"The exact stratigraphical relations of the beds and the relative age of these and contiguous strata have not been as thoroughly investigated as is desirable, and in many cases the particular horizon to which belong the fossils that have been discovered has not been positively determined. According to Prof. Holmes, the phosphate beds are of the post-pliocene period and overlie strata pertaining to the pliocene period and these are again succeeded by a soft marl rock of eocene age, the whole being covered by modern alluvium.

"The phosphatic rocks or nodular masses of the phosphate beds, said to contain as high as sixty, or even more, per centum of calcium phosphate, are of irregular shape, and range in size from small pieces up to masses of a thousand pounds or more. ${ }^{2}$ They contain many casks of molluscous shells, which appear to be of the same forms as those which occur in the eocene or miocene marl rock beneath. They also frequently contain imbedded bones and teeth, mainly those of marine fishes and cetaceans.

"The phosphatic nodules are supposed to have been derived from the tertiary marl bed beneath, and are considered to be detached and altered fragments from the surface of that bed. The irregular, eroded, and porous masses have the appearance of being detached and water-rolled fragments of the tertiary mar rock after it had been tunnelled by various boring molluscs. It is, indeed, not improbable, as has been suggested, that in the later part of the eocene or miocene period and subsequently the easily penetrated rock was bored and rendered spongy by the incessant Iabours of multitudes of Gastrochana, Petricola, Pholas, \&c. At the time or later, neighbouring and superficial islets, the resorts of myriads of sea-fowl, may have furnished the material which, when washed with the ocean and mingled together with the decomposing remains of marine animals, supplied the element for the conversion of the porous marl rock into the more valuable phosphatic compound.

"Besides the phosphatic nodules, the Ashley beds present a remarkable intermixture of the remains of marine and terrestrial animals, consisting of bones, teeth, coprolites, shells, \&c. derived from the contiguous formations of various ages from the early tertiary to those of a comparatively recent period.

"Of remains of vertebrates, those of fishes and cetaceans prevail, especially the teeth of sharks and the vertebræ of whales. Less frequently there occur the vertebræ and teeth of large teleost fishes, the dental pavements of rays, fragments of turtle shells, vertebræ of crocodiles, ear-bones and teeth of cetaceans, bones of manatees, \&c. With these likewise are found the remains of both extinct and still existing terrestrial mammals, especially teeth and bone fragments of elephant and mastodon, megatherium, horse, tapir, bison, and deer. More rarely there are found remains of hipparion, castoroides, hydrochæerus, and of the smaller and more common genera of species.

"The fossils mainly consist of the harder parts of the skeleton and of teeth, usually more or less water-worn, indicating shallow seas and an active surf to which they were exposed. Many of them exhibit the drilling effects of boring molluscs, especially those which are supposed to have been derived from the tertiary marl rock, the operation of drilling apparently having been performed both before and during the time the fossils were embedded in the rock. Only enamel or the enamel-like dentinal $x$ "The Phosphate Rocks of South Carolina." By Francis S. Holmes, A. M., Charleston, 3870 , p. 70 .

A nodular mass, on exlibition in the government building, front Charleston, S. C., weighs 1,150 pounds. 
layer such as is found investing the crown of the teeth of sharks, appears to have been a protection against the drilling power of the borers.

"Fossils excavated from" the phosphate beds are of a ferru. ginous brown colour, but often much lighter or white upon the surface. Those which are obtained from the rivers contiguous to the beds are usually more or less black, with the enamel of teeth iron-gray, and they frequently exhibit the basal attachment of small barnacles, and occasionally the valve of an oyster.

"From the fossils consisting mainly of the harder and denser, and therefore heavier parts of skeletons and teeth, they are generally assumed to be petrified, but usually the change has not been more than a moderate loss of the ostein basis and the infiltration of iron oxyd.

"From the extraordinary variety and profusion of the fossil remains of the Ashley phosphate beds it may be inferred that these were the former rich feeding grounds for multitudes of marine and amphibious animals. At an early period during the formation of the tertiary marl here congregated great sharks, rays, squalodons, \&c. At a later period their successors varied their diet with the carcases of great land animals, as elephants, mastodons, \&c., which foated down the broad and swollen rivers, as drowned herds of the bison are said to do in our day upon the Missouri River.

"Some of the remains of terrestrial animals, comparatively few in number, found as fossils in the Ashley phosphate beds, including cven the softer or more spongey bones, exhibit no evidence of violent water acticin other than the signs of decay from the combined influence of moisture and air ; neither do such fossils exhibit the marks of boring molluscs, nor the attachments of barnacles. Usually black and more or less friable, these fossils, such as the bones of mastodon, megatherium, deer, \&c., are no doubt the remains of animals which became mired and sank into marshes of the Ashley phosphate beds after these had become elevated above the surface of the neighbouring sea. Of this nature, also, we may believe, are the remains of more recent animals, including also specimens of human bones, those of domestic animals, and stone implements, which are cccasionally found in the Ashley phosphate beds."

\section{SCIENTIFIC SERIALS}

American Fournal of Science and Arts, July. - Contributions to meteorology, by E. Loomis (eleventh paper).-Silurian formation in Central Virginia, by J. L. Campbell.-New form of spectrometer, and on the distribution of the intensity of light in the spectrum, by J. W. Draper.-Extinct volcanoes about Lake Mono, and their relation to the glacial drift, by $\mathrm{J}$. Leconte. Mineral locality in Fairfield Co., Connecticut, by G. J. Brush and E. L. Dana (third paper).- Note on the progress of experiments for comparing a wave-length with a metre, by C. S. Peirce.-Recent additions to the marine fauna of the eastern coast of North America, by A. E. Verrill.-Position of the planets Philomela and Adcona, by C. H. F. Peters.-Method of preventing the too rapid combustion of the carbons in the electric lamp, by H. W. Wiley.-Bernardinite, a new mineral resin, by J. M. Stillman.-Notice of a new Jurassic mammal, by O.C. Marsh. - On the Hudson River age for the Taconic schists, by James D. Dana.-(Several of these papers are noticed by us elsewhere.)

Verhandlungen des naturhistorischen Vereins der preussischen Rheinlande und Westfalens (Bonn, vol. 35, parts i. and it., 1878 ). -From these parts we note the following papers:-Section for Geography, Geology, Mineralogy, and Palæontology : Description of the Cotopaxi and its last eruption on June 26,1877 , by Th. Wolf (with plates). - On the eruptive rocks in the Saar and Moselle districts (with plates), by A. von Lasaulx.-Chemical examination of Westphalian and Rhenish rocks and minerals, by W. von der Marck.-New researches on the oldest Devonian formations of the Harz mountains, by C. Schliter.-On some spiders and a myriapod from the brown coal of Rott (with plate), by $\mathrm{Ph}$. Bertkau.-On some ferns from the coal-flora, by Dr. C. J. Andrä.-On some new Cephalopoda from the North German chalk deposits, by C. Schluiter. - On the geology of Italy, by Herr vom Rath.-On O. Volger's new theory of wells and sources, by Dr. Mohr.-On the depths and configurations of the sea-bottoms, by Herr Fischer,-On the crystallisation of cyanite, by Herr vom Rath. - On the natural conditions of Xilberfeld, Barmen, and neighbourhood, by Herr Cornelius,-On the development and importance of coal mining in the Rhinelasd and Westphalia.-On the geognostical conditions of the Oster Wood near Elberfeld, by Herr Buff.-On the mining operations in the Eifel from a historical point of view, by Herr Voss.--On some fossil bones from the Unkelstein, by Herr Schwarze.-On the perception of the earthquake of August 26,1878 , in the Rhenish mines, by Herr Fabricius.-On a fossil elephant's tusk from Hennef in the Sieg Valley, by Herr Buff.-On a löss-like formation in the diluvium of the Weser district, by R. Wagener. -Botanical Section: Further researches on the fertilisation of flowers by insects, by $\mathrm{H}$. Miiller.-On Limodorum abortioum. Sw., and Epipogium gmelini, Rich., by G. Becker.-On Ophris arachnites and $O$. apifera, by the same.-On some rare speci mens from the Rhenish flora, by the same.-On the persistence of flowers and fruits in their position with regard to the horizon, by Herr von Hanstein.-Anatomical and physiological researches on the nectaries of flowers, by Herr Behrens.-On the change of colour in leaves, by Herr Lindemuth.-Section for Anthropology, Zoology, and Anatomy: Herpetological drawing: made by Rosel von Rosenhof (from his posthumous papers), dis cussed by F. Leydig.-On some parasitical hymenoptera, by A. Forster. - On the mollusk fauna of Westphalia, by P. Hesse.-. On the clothes of man compared to the natural coats of animals, by Prof. Troschel.--On the whales occurring on the coasts of Japan, by Herr Mohnike.-On the spermatogenesis of mammals, by Prof. von la Valette St. George.-On the differences between Atypus piceus, Sulz., and $A$. affinis, Eichw, in the female sex, by Herr Bertkan.-On the bats of the Rhineland and Westphalia. On thirty-six species of fish caught in the Rhine near Linz, by Herr Melsheimer.-Section for Chemistry, Technology, Physics, and Astronomy: On the action of prussic acid, by Herr Wallach.-On normal weights made of rock crystal, by Herr Stein. -On a metallurgical work published in Japan in the seventeenth century, by Dr. Gurlt.-On celluloid, by Dr. Köster.-Oi the nature of the force of attraction, by Prof. Mohr.-On the decomposition of salicylate of soda by carbonic acid, by Heri Binz.--On Prof. N ewcomb's researches on the motion of the moon, by Herr Schönfeld.-On the Rott tunnel near Barmen, by Herr Hövel.- On a universal hand-boring machine for harel rocks, by Herr Faber.

Fournal of the Franklin Institute, July.-Power-transmitting mechanism; on the strength of the teeth of wheels, by $\mathrm{Mr}$. Cooper.-Harmonic and basic lines and tendencies, by Dr. Chase. -Committee report on Olsen's testing machine.-Machines for measuring, by Mr. Richards.-The electric arc, its resistance and illuminating power, by Professors Thomson and Houston.Effects of atmospheric changes on textile bands, by Mr. Wocdbury.- Phosphorus in bituminous and anthracite coals, by Mr. Roney.

THE quarterly* Revue des Sciences naturelles (and series, vol. i., No. I).- - On the aphides inhabiting Pistacia terebinthus and $p$. lentiscus, by L. Courchet.-Morphological researches on the family of Graminacex, by D. A. Godron.-On some plants gathered in the neighbourhood of Montpellier in 1877 , by $\mathrm{M}$. Duval Jouve.-Catalogue of the land-and river-molluscs of the Hérault department, by $\mathrm{E}$. Dubrueil.-On the employment of collodion for obtaining microscopical sections, by M. Duval. -Note on the discovery of a layer of imnacidæ-marlstoje (shell-marl) at Celleneuve, near Montpellier, by F. Fontannes. -On the reason of the occasional simultaneous occurrence of limestone plants and silica plants, by $\mathrm{Ch}$. Contejean.

THE Sitzungsberichte der naturwissenschafitichen Gesellschat Isis zu Dresden (1878, part ii., Tuly-December) contain the fo?lowing papers of interest:- On the earthquake observed at Nolhac on July 24 , I 878 , by J. von Boxberg.-On the tertiary basin of Bilin, by Herr Deichmuiller.-On the cones of Glyptostrobus europaus, Brongn., by Herr Engelhardt.-On the bed of the River Priessnitz, near Dresden, by the same.-On J. H. Schmick's work: the sun and moon as constructors of the earth's shell, by Clemens König. The reviewer condemns Herr Sclimick's theory completely, and draws attention to its numerous weak points.-On the mineralogy and geology of the St. Gotthardt, by Herr Roscher._On some abnormal cone formations in pines, by Dr. Nobbe.-On some Swedish plants, by Herr von Biedermann,-On some new results in prehistoric research, by Dr. Geinitz, sen,...On a light machine, by Dr. Töler.-On an elementary derivation of the law of gravitation from Kepler's laws, by Herr Kelm.-On an expedition to the Arctic Ocean and the White Sea, by IIerr Baldauf.-On silicified 